\title{
PENGEMBANGAN MEDIA INTERAKTIF MENGGUNAKAN SOFTWARE AUTHORING TOOLS LECTORA PADA MATA KULIAH KAJIAN MATEMATIKA SMA 2 UNTUK MENINGKATKAN DISPOSISI MATEMATIKA
}

\author{
Laela Sagita \\ Fakultas Keguruan dan Ilmu Pendidikan, Universitas PGRI Yogyakarta \\ sagita.laela@gmail.com
}

\begin{abstract}
This research aims to develop interactive media studies at the high school mathematics course 2 in develop a mathematical disposition effectively and significantly. In this study in the discussion of any matter to be presented in an interactive medium is confined to the concepts, applications, and problem solving (exercises), in future studies researchers aim to equip with a history of a theory, so that students can know the story behind a mathematical theory, as well as the deepening of the material.

This research includes research development (development research). According to Van den Akker and Plomp (Sutrisno Hadi, 2001), that the development of research objectives are: 1) to obtain a prototype product and for the formulation of methodological suggestions, 2) for designing and evaluating a prototype of the product. In this study, researchers divided in several stages, including the stages of preparation, and execution phases of the data analysis stage. The data collection instrument used was a sheet of media validation, observation sheets, and questionnaires. The data collected in the form of data about the quality of the products developed, namely validity, practicality, and effectiveness.

The results of the development of the Interactive Media in Studies High School Mathematics 2 with ADL cycle is (1) Media is developed by the validity criteria, $78.53 \%$ ideals according to experts, $78.50 \%$ ideals according to media expert. Effectiveness shown by average score of 71.07 with a percentage disposition ideality $76.88 \%$ (high). More than $50 \%$ of disposition of student math scores on very high category. Practicality is shown by the response to the students' interactive media in studies high school mathematics 2 with $75.49 \%$ positive response (good). The average score practicality of interactive media is 69,38. (2) Interactive Media in Studies High School Mathematics 2 with ADL cycle have developed mathematical dispositions students effectively and significant.
\end{abstract}

Keywords: interactive media, mathematical disposition

\begin{abstract}
ABSTRAK
Penelitian ini bertujuan untuk mengembangkan media interaktif pada mata kuliah Kajian Matematika SMA 2 yang di dapat menumbuhkembangkan disposisi matematika secara efektif dan signifikan. Pada penelitian ini dalam pembahasan setiap materi yang akan disajikan dalam media interaktif hanya terbatas pada konsep, aplikasi, serta pemecahan masalah (latihan soal), pada penelitian selanjutnya peneliti bertujuan akan melengkapi dengan history dari sebuah teori, sehingga mahasiswa dapat mengetahui kisah dibalik sebuah teori matematika, serta pendalaman materi.

Penelitian ini termasuk jenis penelitian pengembangan (development research). Menurut Van den Akker dan Plomp (Sutrisno Hadi, 2001), bahwa tujuan penelitian pengembangan adalah : 1) untuk mendapatkan prototipe produk dan untuk perumusan saran-saran metodologis, 2) untuk pendesainan dan evaluasi prototipe produk tersebut. Pada penelitian ini peneliti membagi dalam beberapa tahapan, yaitu meliputi tahapan persiapan, tahapan pelaksanaan dan tahapan analisis data. Instrumen pengumpulan data yang digunakan adalah lembar validasi media, lembar observasi, dan
\end{abstract}


angket. Data yang dikumpulkan berupa data tentang kualitas produk yang dikembangkan yaitu kevalidan, kepraktisan, dan keefektifannya.

Hasil dari pengembangan Media Interaktif Kajian Matematika SMA 2 dengan siklus ADL (1) Media dikembangkan dengan memenuhi kriteria kevalidan, persentase keidealan 78,53\% menurut ahli materi, $78.50 \%$ presentase keidealan menurut ahli media. Kefektifan ditunjukkan melalalui rata-rata skor disposisi 71,07 dengan presentase keidealan 76,88\% (tinggi). Lebih dari 50\% skor disposisi matematika mahasiswa dengan kategori sangat tinggi. Kepraktisan ditunjukkan dengan respon mahasiswa terhadap terhadap media interaktif pada mata kuliah Kajian Matematika SMA 75,49\% respon positif (baik). Rata-rata skor kepraktisan media interaktif 69,38. (2) Media interaktif dengan siklus ADL pada mata kuliah Kajian Matematika SMA 2 yang dikembangkan telah menumbuhkembangkan disposisi matematika mahasiswa secara efektif dan signifikan

Kata Kunci: media interaktif, disposisi matematika

\section{Pendahuluan}

\section{Latar Belakang Masalah}

Perubahan kurikulum di tingkat sekolah yang sebelumnya mengunakan Kurikulum Tingkat Satuan Pendidikan (KTSP) menjadi Kurikulum 2013 dimana menekankan pada kemampuan sikap, pengetahuan, dan keterampilan pada siswa harus disikapi dengan serius oleh Lembaga Pendidik Tenaga Kependidikan (LPTK) yang akan mencetak calon guru. Karena seorang calon guru harus disiapkan dengan segala perubahan yang mungkin terjadi, dimana salah satunya adalah perubahan kurikulum, hal ini menuntut seorang guru untuk dapat dengan cepat melakukan penyesuaian. Implikasinya adalah mahasiswa calon guru selayaknya memiliki sikap percaya diri, tanggung jawab, tekun, pantang putus asa, merasa tertantang, memiliki kemauan untuk mencari cara lain, dan melakukan refleksi terhadap cara berfikir yang telah dilakukan. Diharapkan jika sikap tersebut dimiliki oleh mahasiswa sebagai calon guru, maka akan dengan mudah dapat melakukan penyesuaian dengan segala perubahan yang terjadi.

Salah satu mata kuliah di Program Studi Pendidikan Matematika yang mengkaji mengenai materi tingkat sekolah menengah terdiri dari 12 SKS dan tersaji dalam 4 mata kuliah, diantaranya Kajian Matematika SMP 1, Kajian Matematika SMP 2, Kajian Matematika SMA1, dan Kajian Matematika SMA 2. Dengan memperhatikan kurikulum 2013 ditingkat sekolah yang seyogyanya akan digunakan sampai dengan beberapa kedepan dan memperhatikan deskripsi dari mata kuliah kajian matematika, yaitu mahasiswa dapat menguasai materi pada tingkat sekolah menengah. Hal ini terlihat bahwa materi yang harus dikuasai oleh mahasiswa pada mata kuliah Kajian Matematika sangat banyak yaitu pada Kajian Matematika SMP terdiri dari 20 bab, sedangkan pada Kajian Matematika SMA terdiri 21 bab, dari harus menyesuaikan dengan setiap perubahan kurikulum di tingkat sekolah menengah. 
Banyaknya materi pada mata kuliah kajian matematika dirasakan baik oleh dosen dan mahasiswa. Hal ini tidak sebanding dengan waktu tatap muka yang tersedia selama satu semester yaitu 14 tatap muka, karena pada mata kuliah ini mengkaji materi-materi SMP dan SMA secara lebih mendalam. Pada tahun 2012/2013, sebanyak 35\% tingkat kelulusan mahasiswa pada matakuliah Kajian Matematika kurang dari C. Pada umumnya, kesalahan yang dilakukan oleh mahasiswa adalah mahasiswa kurang bisa mengimplementasi konsep-konsep untuk menyelesaikan masalah. Lebih lanjut dari hasil wawancara terungkap bahwa mahasiswa kurang memiliki sikap gigih dalam mencari solusi dari permasalahan yang tersaji hal ini terlihat saat mahasiswa diberikan permasalahan atau soal yang berbeda dengan tingkat penyelesaian yang sedikit tinggi mereka mengalami kesulitan, serta rasa keingintahuan mahasiswa masih kurang. Hal ini dikarenakan mahasiswa merasa konsep dan materi yang mereka peroleh tidak maksimal seperti tersebut sebelumnya.

Mata kuliah Kajian Matematika SMP dan SMA merupakan salah satu prasyarat dalam pengambilan mata kuliah selanjutnya, yaitu Pengajaran Mikro dimana mahasiswa belajar mengajar. Berdasarkan hasil wawancara pada mahasiswa yang telah mengambil mata kuliah pengajaran mikro, mahasiawa akan lebih memiliki rasa percaya diri saat sudah menguasai materi yang akan digunakan dalam praktek di kelas. Hal ini didukung oleh pernyataan beberapa dosen pengampu mata kuliah Pengajaran Mikro, bahwa salah satu faktor pendukung dalam keberhasilan mahasiswa pada praktek mikro adalah penguasaan terhadap materi.

Kompetensi yang harus dikuasai oleh mahasiswa pada mata kuliah Kajian Matematika SMA 2 adalah mahasiswa memiliki kemampuan berfikir tingkat tinggi, punya penghargaan terhadap matematika, objektif dan terbuka, serta rasa ingin tahu dan senang belajar matematika. Konsistensi sikap seperti ini akan menumbuhkan disposisi matematika yaitu sikap produktif akibat belajar matematika sehingga menumbuhkan sikap positif dan kebiasaan untuk melihat matematika sebagai sesuatu yang logis, berguna dan bermanfaat.

Berdasarkan beberapa permasalahan dan data yang tersebut sebelumnya dosen mata kuliah kajian matematika sebagai peneliti membuat sebuah solusi yaitu pembelajaran mata kuliah kajian matematika SMA 2 menggunakan media interaktif. Dengan menggunakan media interaktif diharapkan dapat menjadi jalan keluar untuk ketersediaaan tatap muka yang terbatas. Penggunaan media dalam proses pembelajaran memiliki berbagai kegunaan, diantaranya dapat mengatasi 
perbedaan gaya belajar, minat, dan sikap mahasiswa. Selain itu, media yang digunakan secara tepat dan bervariasi dapat mengatasi sikap pasif anak didik. Dengan media interaktif ini, diharapkan dapat meningkatkan sikap percaya diri, tanggung jawab, ketekunan, pantang putus asa, merasa tertantang, serta mahasiswa memiliki kemauan untuk mencari cara lain dalam menyelesaikan masalah, dan melakukan refleksi terhadap cara berfikir yang telah dilakukan.

\section{Rumusan Masalah}

Berdasarkan latar belakang masalah yang telah diuraikan di atas, maka masalah yang akan dibahas dalam penelitian ini adalah :

1. Apakah media interaktif mata kuliah Kajian Matematika Sekolah yang dikembangkan memenuhi kriteria kevalidan, keefektifan, dan kepraktisan?

2. Apakah media interaktif yang dikembangkan dapat menumbuhkembangkan disposisi matematika mahasiswa secara efektif dan signifikan?

Dalam penelitian ini media interaktif yang dimaksud adalah Media pembelajaran yaitu sebuah alat yang berfungsi menyampaikan pesan pembelajaran. Sedangkan disposisi matematika yang dimaksud adalah sikap produktif akibat belajar matematika sehingga menumbuhkan sikap positif dan kebiasaan untuk melihat matematika sebagai sesuatu yang logis, berguna dan bermanfaat.

\section{Kajian Literatur dan Pengembangan Hipotesis}

\section{Disposisi Matematika}

Dalam proses belajar mahasiswa cenderung membutuhkan rasa percaya diri dan kegigihan dalam menghadapi setiap masalah yang diberikan. Sikap yang demikian harus senantiasa dikembangkan dan dipertahankan melalui penciptaan suasana belajar yang menarik minat siswa dan cenderung menantang untuk dieksplorasi. Dengan keadaan tersebut, diharapkan dapat menciptakan sebuah keyakinan dalam diri siswa bahwa mereka mampu belajar dengan rasa percaya diri dan senang terhadap matematika. Konsistensi sikap seperti ini akan menumbuhkan disposisi matematika

Polking dalam Utari Sumarmo (2010) disposisi matematika menunjukkan bahwa (1) kepercayaan diri dalam menggunakan matematika, (2) fleksibilitas dalam menyelidiki gagasan matematis, (3) tekun dalam mengerjakan tugas matematika, (4) mempunyai minat belajar dan rasa keingitahuan yang tinggi terhadap persoalan matematis.

Martadiputra (2012) mengartikan disposisi matematika sebagai kecenderungan seseorang mahasiswa untuk berpikir dan berbuat dengan cara yang positif dan konstruktif yang berlangsung dalam kegiatan matematis. 
Selanjutnya Martadiputra (2012) membagi disposisi statistis ke dalam tujuh dimensi, yaitu: 1) gairah dan perhatian serius dalam belajar; 2) rasa percaya diri; 3) fleksibilitias dalam mengeksplorasi ide dan alternatif pemecahan masalah; 4) kegigihan dalam menghadapi dan menyelesaikan masalah; 5) memonitor dan refeksi pemikiran; 6) rasa ingin tahu yang tinggi; dan 7) berbagi pendapat dengan orang lain.

Menurut Standar 10 NCTM (Utari Sumarmo, 2010) mengemukakan bahwa disposisi matematika menunjuk pada rasa percaya diri, ekspektasi dan metakognisi, gairah dan perhatian serius dalam belajar matematika, kegigihan dalam menghadapi dan menyelesaikan masalah, rasa ingin tahu yang tinggi, serta kemampuan berbeda pendapat dengan orang lain. Disposisi matematika juga adapat dilihat sebagai sikap produktif akibat belajar matematika sehingga menumbuhkan sikap positif dan kebiasaan untuk melihat matematika sebagai sesuatu yang logis, berguna dan bermanfaat.

Berdasarkan pendapat tersebut, indikator disposisi matematika dalam kegiatan ini adalah:

a. Rasa percaya diri dalam menggunakan matematika, memecahkan masalah, memberi alasan dan mengkomunikasikan gagasan.

b. Fleksibilitas dalam menyelidiki gagasan matematika dan berusaha mencari metode alternatif dalam memecahkan masalah.

c. Tekun mengerjakan tugas matematika.

d. Minat, rasa ingin tahu dan daya temu dalam melakukan tugas matematika

\section{Media Interaktif}

Media adalah sebuah alat ayang berfungsi menyampaikan pesan (Bovee, 1997). Media pembelajaran adalah sebuah alat ayang berfungsi menyampaikan pesan pembelajaran. Salah satu inovasi dalam media pembelajaran adalah penggunaan media interaktif dalam pembelajaran. Implementasi model-model pembelajaran interaktif berbasis komputer adalah dengan pemanfaatan dalam setting pembelajaran didalam kelas maupun diluar kelas.

Menurut Rusman dalam Nandi (2006), bentuk-bentuk pemanfaatan model-model media interaktif berbasis komputer dapat berupa driil, tutorial, simulasi dan games. Model media interaktif dalam kegiatan ini adalah model tutorial. Model tutorial adalah model pembelajaran interaktif yang digunakan dalam PBM dengan menggunakan perangkat lunak berupa program komputer berisi materi kuliah. Penekananya terletak pada upaya berkesinambungan untuk memaksimalkan aktivitas belajar mengajar sebagai interaksi kognitif antara siswa, subjek materi dan komputer yang diprogram. 
Secara sderhana pola-pola pengoperasian komputer sebagai instruktur pada model tutorial ini yaitu:

1. Komputer menyajikan materi

2. Siswa memberikan respon

3. Respon siswa dievaluasi oleh komputer dengan orientasi pada arah siswa dalam menempuh prestasi selanjutnya

4. Melanjutkan atau mengulangi tahapan selanjutnya

Tutorial dalam program pembelajaran interaktif ditujukan sebagai pengganti manusia sebagai instruktur secara langsung pada kenyataannya diberikan berupa teks atau grafik pada layar yang telah menyediakan poin-poin pertanyaan atau permasalahan.

\section{Lectora Inspire}

Lectora Inspire adalah sebuah program komputer yang merupakan tool (alat) pengembangan belajar elektronik (e-learning), dikembangkan oleh Perusahaan Trivantis Corporation. Pendirinya adalah Timothy D. Loudermilk di Cincinnati, Ohio, Amerika tahun 1999.

\section{Authoring Tool Lectora} merupakan salah aplikasi komputer yang digunakan untuk membuat media ajar interaktif. Aplikasi ini dapat bekerja pada komputer under Windows, artinya hanya dapat digunakan pada komputer dengan Sistem Operasi (SO) Windows. Namun, saat ini baru dapat berjalan pada komputer yang menggunakan SO Windows XP dan Windows 7.

Lectora Inspire memiliki antarmuka yang familiar dengan kita yang telah mengenal maupun menguasai Microsoft Office. Antarmuka Lectora Inspire terbagi dalam 3 hal utama, yakni Menu dan Toolbar, Title Explorer, dan Work Area. Menu-menu yang ada di dalam Lectora, hampir sama dengan menu-menu yang berada dalam programprogram Microsoft Office. Menu-menu itu antara lain File, Edit, Add, Layout, Tools, Mode, Publish, View, dan Help.

Title Explorer merupakan pohon direktori yang menampilkan semua objek, chapter, section, dan page yang terdapat dalam work area Lectora. Work Area sendiri merupakan area kerja Lectora, dimana didalamnya kita dapat melakukan editing media pembelajaran. Yang patut dicatat dan diperhatikan, semua objek, level, chapter, section dan page dalam work area ini memiliki levellevel tertentu, yang digambarkan dalam pohon direktori title explorer. Level tertinggi berada langsung di bawah judul/title dari konten media pembelajaran kita, menyusul kemudian di bawahnya level chapter/bab, level section/sub bab, dan yang terbawah adalah level page / halaman.

Lectora Inspire, dari awal software ini diciptakan memang untuk kebutuhan e-learning. Lectora Inspire dapat digunakan untuk kebutuhan 
pembelajaran baik online maupun offline yang dapat dibuat dengan mudah dan cepat. Lectora Inspire dapat digunakan untuk menggabungkan flash, merekam video, menggabungkan gambar, dan screen capture.

\section{Metode Penelitian}

\section{Metode}

Penelitian ini termasuk jenis penelitian pengembangan (development research). Menurut Van den Akker dan Plomp , bahwa tujuan penelitian pengembangan adalah : 1) untuk mendapatkan prototipe produk dan untuk perumusan saran-saran metodologis, 2) untuk pendesainan dan evaluasi prototipe produk tersebut. Produk yang dikembangkan adalah perangkat pembelajaran berupa Media Interaktif yang digunakan pada saat perkuliahan Kajian Matematika SMA 2. Setelah pengembangan perangkat pembelajaran, berikutnya dilaksanakan penelitian eksperimen yang bertujuan melihat keefektifan media interaktif dalam meningkatkan disposisi matematika mahasiswa dengan menggunakan perangkat pembelajaran yang telah dikembangkan.

\section{Prosedur}

$$
\text { Pada penelitian ini peneliti }
$$
membagi dalam beberapa tahapan, yaitu meliputi tahapan persiapan, tahapan pelaksanaan dan tahapan analisis data.

1. Tahapan Persiapan
Dalam tahapan persiapan kegiatan yang dilakukan adalah :

a. Mempelajari literatur tentang model pembelajaran yang dapat digunakan dalam pembelajaran Kajian Matematika SMA2 dengan menggunakan media interaktif.

b. Menganalisis deskripsi mata kuliah Kajian Matematika SMA 2 dan menganalisa materi yang akan dikembangkan.

c. Menyusun flow chart dan storyboard media yang akan digunakan dalam tahap pengembangan media interaktif.

2. Tahapan Pengembangan

Dalam tahapan pelaksanaan kegiatan yang dilakukan adalah mengembangkan media interaktif. Pada tahap ini peneliti melakukan kegiatan:

a. Menyusun media interaktif

b. Mereview media interaktif yang dilakukan beberapa orang pakar (pengkajian dan expertjudment)

c. Merevisi media berdasarkan masukan oleh pakar

d. Uji coba keterbacaan media dalam skala kecil dilakukan dengan melihat beberapa aspek kelayakan isi, pembelajaran, tampilan, dan pemrograman. Perbaikan media akan dilakukan berdasarkan masukan-masukan dalam uji coba skala kecil.

e. Revisi produk media interaktif 
f. Uji coba di kelas, pada kegiatan ujicoba di kelas ada beberapa metode pengumpulan data yang akan dilakukan dengan menggunakan angket terkait respon mahasiswa dalam mengunakan media, termasuk pula angket dispoisisi matematika.

3. Tahapan Evaluasi

Kegiatan pengecekean efektivitas dan kepraktisan media interaktif Kajian Matematika Sekolah SMA 2 yaitu melakukan evaluasi dari beberapa instrument :

a. Pengecekan efektivitas ini dilakukan dengan memberikan angket respon mahasiswa setelah diberikan perlakuan media interaktif, dan angket disposisi matematika sebelum dan sesudah menggunakan media interaktif Kajian Matematika SMA 2, kemudian hasilnya dianalisis dan dideskripsikan secara kuantitatif.

b. Evaluasi terhadap kepraktisan media interaktif dilakukan melalui analisis lembar evaluasi kepraktisan penggunaan media interaktif yang dilakukan oleh dosen lain diluar tim peneliti yang mengampu mata kuliah Kajian Matematika SMA 2.

Alat pengumpul data pada tahap evaluasi ini berupa lembar evaluasi kepraktisan, lembar penilaian skala kecil, serta angket respon mahasiswa dan disposisi matematika. a. Lembar evaluasi kepraktisan digunakan untuk mengukur kepraktisan media interaktif mata kuliah Kajian Matematika SMA 2 pada. Evaluasi ini dilakukan oleh dosen Pendidikan Matematika diluar tim peneliti.

b. Lembar penilaian skala kecil digunakan untuk mengukur kepraktisan dari keterbacaan media interaktif oleh mahasiswa dalam skala kecil.

c. Lembar angket respon mahasiswa dan pedoman wawancara digunakan untuk mengetahui tanggapan mahasiswa dengan media yang digunakan dalam perkuliahan.

d. Lembar angket disposisi matematika digunakan untuk mengetahui profil disposisi matematika mahasiswa setelah menggunakan media yang telah dirancang.

\section{Hasil dan Pembahasan}

\section{Evaluasi Kepraktisan Media}

Evaluasi terhadap kepraktisan media interaktif dilakukan melalui analisis lembar evaluasi kepraktisan penggunaan media interaktif yang dilakukan oleh dosen lain diluar tim peneliti yang mengampu mata kuliah Kajian Matematika SMA 2.

Data yang diperoleh kemudian dianalisis secara kuantitatif, berikut hasil 
analisis data kepraktisan media interaktif Kajian Matematika SMA 2.

Tabel 4.1. Hasil Analisis Penilaian

Kepraktisan Media Interaktif Kajian Matematika SMA 2

\begin{tabular}{|c|c|c|c|}
\hline $\begin{array}{cc}\mathbf{N} & \text { Aspek yang } \\
\mathbf{0} & \text { Dinilai }\end{array}$ & $\begin{array}{c}\text { Rerata } \\
\text { Skor Per } \\
\text { Aspek }\end{array}$ & $\begin{array}{c}\text { Keidea } \\
\text { lan } \\
(\%)\end{array}$ & Kategori \\
\hline 1. Kelayakan Isi & 55,5 & 79,29 & Baik \\
\hline 2. Pembelajaran & 60 & 80 & $\begin{array}{l}\text { Sangat } \\
\text { baik }\end{array}$ \\
\hline 3. Tampilan & 83 & 83 & $\begin{array}{c}\text { Sangat } \\
\text { baik }\end{array}$ \\
\hline 4. Pemrograman & 79 & 79 & Baik \\
\hline JUMLAH & 69,38 & 86,25 & $\begin{array}{c}\text { Sangat } \\
\text { baik }\end{array}$ \\
\hline
\end{tabular}

Rerata skor dari semua aspek pada

ujicoba kelompok kecil ini sebesar 69,38, hal ini menunjukkan bahwa media interaktif Kajian Matematika SMA 2 dalam kategori baik.

\section{Angket Respon Mahasiswa}

Respon mahasiswa terhadap media interaktif diukur dengan menggunakan instrument angket. Untuk selanjutnya angket dianalisis secara kuantitatif. Tabel analisis data respon mahasiswa terhadap media interaktif disajikan pada tabel 4.2.

Tabel 4.2. Hasil Analisis Data Respon Mahasiswa terhadap Media Interaktif Kajian Matematika SMA 2

\begin{tabular}{llccl}
\hline No & Aspek & $\begin{array}{c}\text { Skor } \\
\text { total } \\
\text { per } \\
\end{array}$ & $\begin{array}{c}\text { Presen } \\
\text { tase } \\
(\%)\end{array}$ & $\begin{array}{c}\text { Katago } \\
\text { ri }\end{array}$ \\
\hline & & & \\
\hline 1. & Perhatian & 625 & 72.34 & Baik \\
\hline 2. & Keterkaitan & 329 & 76.16 & Baik \\
3. & Keyakinan & 330 & 76.39 & Baik \\
\hline 4. & Kepuasan & 333 & 77.08 & Baik \\
\hline & Jumlah & 1617 & 75.49 & Baik \\
\hline
\end{tabular}

Berdasarkan hasil analisis dari data tersebut, dapat disimpulkan bahwa respon mahasiswa untuk seluruh aspek maupun peraspek menunjukkan respon positif (baik).

\section{Pengecekan Keefektifan}

Evaluasi terhadap keefektifan media interaktif dilakukan melalui analisis angket disposisi matematika mahasiswa setelah menggunakan media interaktif kuliah Kajian Matematika SMA 2.

Dari 26 mahasiswa, kelompok mahasiswa yang mendapatkan skor disposisi dengan kategori sangat baik sejumlah 15 mahasiswa, sedanglkan 11 lainnya masuk dalam kategori tinggi. Tabel berikut menunjukkan skor disposisi matematika dari tiap karegori.

Tabel 4.3 Skor Disposisi Matematika Per Kategori

\begin{tabular}{lcccc}
\hline & \multicolumn{4}{c}{ Skor Disposisi Matematika } \\
& \multicolumn{4}{c}{ Mahasiswa } \\
\hline Kategori & Sangat & Tingg & Seda & Rend \\
Skor & Tinggi & i & ng & ah \\
Banyak & 15 & 11 & 0 & 0 \\
Mahasiswa & & & & \\
$\begin{array}{l}\text { Prosentase } \\
(\%)\end{array}$ & 57.69 & 42.31 & & \\
\hline
\end{tabular}

Sesuai dengan indikator keefektifan dari media interaktif yang disebutkan pada bab III, bahwa jika skor mahasiswa dengan kategori sangat tinggi lebih dari 50\%, maka media ninteraktif yang digunakan pada mata Kuliah Kajian Matematika SMA 2 berhasi (efektif) menumbuhkemban kan disposisi 
matematika mahasiswa. Berdasarkan tabel 5.7 persentase skor mahasiswa dengan kategori sangat tinggi yaitu $57.69 \%$, dapat disimpulkan bahwa pengembangan media interaktif dengan menggunakan siklus ADL pada mata kuliah Kajian Matematika SMA 2 berhasil untuk menumbuh kembangkan disposisi matematika mahasiswa.

Signifikasi efektivitas penggunaan media interaktif pada mata kuliah Kajian Matematika SMA 2 dilakukan dengan uji statistik yaitu dengan uji-t satu sampel, dengan terlebih dahulu dilakukan uji normalitas dengan bantuan Software SPSS 16.0. Hasil uji normalitas dengan hasil untuk uji normalitas Kolmogorov-Smirnov skor disposisi matematika memiliki nilai $p=$ 0.200, sedangkan untuk uji normalitas Shapiro-Wilk nilai $p=0.812$. Kedua nilai $p$ untuk uji normalitas lebih dari $\alpha=0.05$, sehingga $\mathrm{H}_{0}$ diterima yaitu data berasal dari populasi yang berdistribusi normal.

Hasil analisis data disposisi matematika menggunakan uji-t adalah sebagai berikut.

Tabel 4.4 Hasil Uji-t Signifikansi Penggunaan Media Interaktif Kajian Matematika SMA 2 untuk Meningkatkan Disposisi Matematika

One-Sample Test

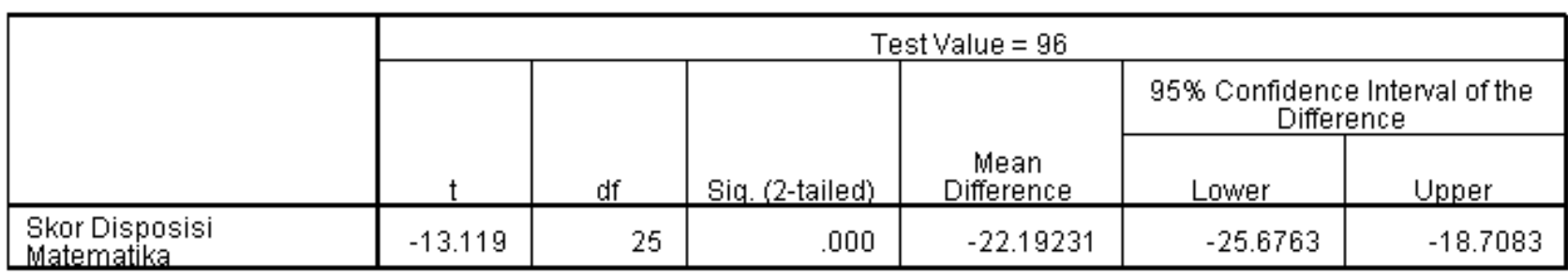

Uji-t pada tabel 5.9 digunakan untuk menguji $\mathrm{H}_{0}$ : proporsi mahasiswa dengan kategori disposisi matematika sangat tinggi $\leq 0,5$ terhadap Ha: proporsi mahasiswa dengan kategori disposisi matematika sangat tinggi $>0,5$. Nilai uji t yang diperoleh adalah 13,113 dengan derajat kebebasan $\mathrm{t}=\mathrm{n}-1=26-1=25$. Karena nilai p sama dengan 0,000 dengan $\alpha=0,05$ sehingga $\mathrm{H}_{0} \quad$ : proporsi mahasiswa dengan kategori disposisi matematika sangat tinggi $\leq 0,5$ ditolak. Dengan kata lain Ha: proporsi mahasiswa dengan kategori disposisi matematika sangat tinggi > 0,5 diterima. Jadi dapat disimpulkan bahwa proporsi mahasiswa dengan dengan kategori disposisi matematika sangat tinggi lebih dari 0,5. Berdasarkan keadaan ini, menunjukkan bahwa penggunaan media interaktif pada mata kuliah kajian matematika SMA 2 yang dikembangkan dapat meningkatkan disposisi matematika secara efektif.

\section{Kesimpulan}

Kesimpulan dari kegiatan pengembangan ini adalah :

1. Media Interaktif Kajian Matematika SMA 2 dengan siklus ADL yang 
dikembangkan memenuhi kriteria kevalidan, keefektifan, dan kepraktisan.

a. Kriteria kevalidan dapat ditunjukkan melalui penilaian ahli materi dan media, menurut ahli materi menunjukkan dalam kategori baik dengan persentase keidealan $78,53 \%$, sedangkan menurut ahli media menunjukkan dalam kategori baik dengan persentase keidealan $78.50 \%$.

b. Kriteria keefektifan media interaktif yang telah dikembangkan dapat dilihat dari hasil angket disposisi matematika. Rata-rata skor disposisi matematika setelah mahasiswa menggunakan media interaktif pada mata kuliah Kajian Matemtika SMA 2 71,07 dengan presentase keidealan $76,88 \%$ dengan kategori tinggi. Jumlah mahasiswa yang memiliki skor disposisi matematika dengan kategori sangat tinggi lebih dari $50 \%$.

c. Kriteria kepraktisan media interaktif mata kuliah Kajian Matematika SMA 2dilihat dari hasil analisis data respon mahasiswa dan lembar evaluasi kepraktisan media interaktif.

1) Respon mahasiswa terhadap terhadap media interaktif pada mata kuliah Kajian Matematika SMA menunjukkan $75,49 \%$ mahasiswa memiliki respon positif (baik) terhadap media interaktif dengan siklus ADL.

2) Rata-rata skor kepraktisan media interaktif yang telah dikembangkan adalah 69,38 dengan persentase keidealan $86,25 \%$,

2. Media interaktif dengan siklus ADL pada mata kuliah Kajian Matematika SMA 2 yang dikembangkan telah menumbuhkembangkan disposisi matematika mahasiswa secara efektif dan signifikan

\section{Pustaka}

Abdul Aziz 2013. Pengembangan Bahan Ajar Mata Kulish Aljabar Linear Elementer (ALE) Berdasarkan Model Pembelajaran APOS untuk Menumbuhkembangkan Daya Matematika dan Disposisi Matematika. Laporan Hibah Pengajaran UPY.

Bovee, Courland. 1997. Bussines Communications Today, Prentice Hall. New York

Nandi. (2006). Penggunaan Multimedia Interaktif dalam Pembelajaran geografi di Persekolahan.6:3-6 Pengembangan ... (Laela Sagita) 
Bambang Avip Priatna Martadipura. 2012. Disposisi Statistis Mahasiswa Dalam Pembelajaran Statistika Dasar. 1:169-170

Utari Sumarmo. 2010. Berpikir dan Disposisi Matematik: Apa, Mengapa dan Bagaimana Dikembangkan pada Peserta Didik (Makalah). Bandung: FMIPA UPI.
Plomp. Tj. 1997. Educational Design : Introduction From Tjeerd Plomp (eds). Educational \& Training System design : Introduction. Design of education and Training (in Dutch). Utrecht (the Netherland): Lemma. Netherland. Faculty of Educational Science and Technology, University of Twente. Enschede the Netherands. 